\title{
Preincubation with a low-dose hydrogen peroxide enhances anti-oxidative stress ability of BMSCs
}

Lei Wang ${ }^{1,2 \dagger}$, Fei Zhang ${ }^{1,2+}$, Wuxun Peng ${ }^{1,2^{*}}$, Jian Zhang ${ }^{1,2^{*}}$, Wentao Dong ${ }^{1,2}$, Dajiang Yuan ${ }^{2}$, Zhenwen Wang ${ }^{2}$ and Yinggang Zheng ${ }^{2}$

\begin{abstract}
Objective: To investigate the effects of low-concentration hydrogen peroxide pretreatment on the anti-oxidative stress of the bone marrow mesenchymal stem cells (BMSCs).

Methods: Rabbit BMSCs were isolated and cultured by density gradient centrifugation combined with the adherence method. Then, the third generation of well-grown BMSCs was continuously treated with 50- $\mu \mathrm{M}$ hydrogen peroxide $\left(\mathrm{H}_{2} \mathrm{O}_{2}\right)$ for $8 \mathrm{~h}$ as the optimal pretreatment concentration and the BMSCs were continuously applied for $24 \mathrm{~h}$ with $500 \mu \mathrm{M} \mathrm{H}_{2} \mathrm{O}_{2}$, and the optimal damage concentration was determined as the oxidative stress cell model. The experiment was divided into three groups: control group, high-concentration $\mathrm{H}_{2} \mathrm{O}_{2}$ injury group $(500 \mu \mathrm{M})$, and low-concentration $\mathrm{H}_{2} \mathrm{O}_{2}$ pretreatment group $(50 \mu \mathrm{M}+500 \mu \mathrm{M})$. In each group, the DCFH-DA fluorescence probe was used to detect the reactive oxygen species (ROS). ELISA was used to detect the activity of superoxide dismutase (SOD) and catalase (CAT), and the TBA method was used to detect malondialdehyde (MDA). The mitochondrial membrane potential was detected by JC-1. The cell viability was detected by CCK-8 method, while flow cytometry and TUNEL/DAPI double staining were performed to detect cell apoptosis. Hence, the effect of $\mathrm{H}_{2} \mathrm{O}_{2}$ pretreatment on the anti-oxidative stress of BMSCs was investigated. One-way analysis of variance was performed using SPSS 19.0 statistical software, and $P<0.05$ was considered statistically significant.
\end{abstract}

Results: A large number of typical BMSCs were obtained by density gradient centrifugation and adherent culture. The oxidative stress cell model was successfully established by $500-\mu \mathrm{M} \mathrm{H}_{2} \mathrm{O}_{2}$. Compared with the highconcentration $\mathrm{H}_{2} \mathrm{O}_{2}$ injury group, the low-concentration $\mathrm{H}_{2} \mathrm{O}_{2}$ pretreatment reduced the production of ROS [ 62.33 $\pm 5.05), P<0.05]$, SOD and CAT activities significantly increased $(P<0.05)$, and MDA levels significantly decreased $(P$ $<0.05)$. The mitochondrial membrane potential fluorescence changes, the ratio of red/green fluorescence intensity of the high-concentration $\mathrm{H}_{2} \mathrm{O}_{2}$ injury group was less, and the ratio of the low-concentration $\mathrm{H}_{2} \mathrm{O}_{2}$ pretreatment group was significantly higher than that. The ratio of red/green increased by about 1.8 times $(P<0.05)$. The cell viability and survival rate of BMSCs were significantly increased in low-concentration $\mathrm{H}_{2} \mathrm{O}_{2}$ pretreatment group $(P<$ $0.05)$, and the cell apoptosis rate was significantly decreased $(P<0.05)$.

(Continued on next page)

\footnotetext{
*Correspondence: pwx200228@aliyun.com; pwx200228@aliyun.com

${ }^{\dagger}$ Lei Wang and Fei Zhang are co-authors in this work.

'Department of Orthopedics, The Affliated Hospital of Guizhou Medical

University, Guiyang 550004, Guizhou, China

Full list of author information is available at the end of the article
}

\section{$\triangle B M C$}

C C The Author(s). 2020 Open Access This article is licensed under a Creative Commons Attribution 4.0 International License, which permits use, sharing, adaptation, distribution and reproduction in any medium or format, as long as you give appropriate credit to the original author(s) and the source, provide a link to the Creative Commons licence, and indicate if changes were made. The images or other third party material in this article are included in the article's Creative Commons licence, unless indicated otherwise in a credit line to the material. If material is not included in the article's Creative Commons licence and your intended use is not permitted by statutory regulation or exceeds the permitted use, you will need to obtain permission directly from the copyright holder. To view a copy of this licence, visit http://creativecommons.org/licenses/by/4.0/ The Creative Commons Public Domain Dedication waiver (http://creativecommons.org/publicdomain/zero/1.0/) applies to the data made available in this article, unless otherwise stated in a credit line to the data. 
(Continued from previous page)

Conclusion: Pretreatment with low-concentration $\mathrm{H}_{2} \mathrm{O}_{2}$ can enhance the anti-oxidative stress ability and reduce their apoptosis of BMSCs under oxidative stress.

Keywords: Bone marrow mesenchymal stem cells, Oxidative stress injury, Pretreatment, Hydrogen peroxide, Apoptosis

\section{Background}

BMSCs are pluripotent stem cells that have the potential for multi-directional differentiation [1]. In recent years, due to its high proliferative capacity and high differentiation ability, it has attracted widespread attention in stem cell research. At present, the use of BMSC transplantation for the treatment of injury has been proven to be a very promising [2-4]. However, clinical practice and experiments have shown that ischemia, hypoxia, and inflammatory cell infiltration in the injured area produce a large amount of ROS, forming an oxidative stress microenvironment. This results in the death of most of the transplanted BMSCs within $24 \mathrm{~h}$ after transplantation, badly affecting the transplantation [5]. How to improve the survival rate of cells after transplantation is an urgent problem to be solved in clinical research and application of stem cells.

Oxidative stress is the key cause of death of transplanted BMSCs [6]. The important mechanism is that the oxidative stress microenvironment in the osteonecrosis area increases the production of ROS and/or decreases the ability of scavenging ROS, resulting in an imbalance between the production and clearance of ROS $[7,8]$. Excessive ROS can increase mitochondrial membrane permeability, mitochondrial swelling, mitochondrial permeability (mMPTP) opening, and mitochondrial DNA (mtDNA) damage. This leads to dysfunction of mitochondrial electron transport chain, disturbance of tricarboxylic acid cycle, disturbance of ATP synthesis, decrease of transmembrane potential, release of cytochrome C, activation of Caspase-9, formation of caspasedependent apoptosis pathway, and final induction of BMSCs apoptosis [9]. Therefore, determining how to eliminate excessive ROS to enhance the survival and anti-apoptosis ability of transplanted stem cells is the key to improve the effective utilization of stem cells and enhance the therapeutic effect.

Adaptive cytoprotection refers to the application of "sub-traumatic" factors or "survival-promoting" factors to stimulate cells in advance in order to reduce the damage to cells caused by subsequent more serious damage factors [10]. Therefore, We hypothesized that oxidative stress pretreatment of BMSCs can enhance its antioxidant stress, thereby enhancing the survival and proliferation of BMSCs in the necrotic zone, thus improving the therapeutic effect of transplantation. The present study established an oxidative stress cell model by $\mathrm{H}_{2} \mathrm{O}_{2}$, and BMSCs were treated with the best pretreatment concentration and the best damage concentration and observed the survival of BMSCs under different concentrations of $\mathrm{H}_{2} \mathrm{O}_{2}$. Furthermore, the effect of low-concentration hydrogen peroxide pretreatment on the anti-oxidative stress ability of BMSCs was evaluated, providing a theoretical basis for improving the efficacy of BMSC transplantation.

\section{Materials and methods \\ Animals}

In the present study, 4-6-week-old specific pathogenfree (SPF) male New Zealand white rabbits $(1.0-2.0 \mathrm{~kg}$ ) were provided by the Animal Research Center of Guizhou Medical University.

\section{Instruments and reagents}

Desktop high-speed refrigerated centrifuge (Allegra 64R High Speed Centrifuge, Beckman, USA); flow cytometry (Navios; Beckman, USA); multi-function microplate reader (Synergy; Biotech, USA); inverted fluorescence microscope (DM1LLED; Leica, Germany); laser confocal microscopy (LSM710; ZEISS, Germany); DMEM medium, fetal bovine serum, and trypsin (Gibco, New Zealand); $\mathrm{H}_{2} \mathrm{O}_{2}$ (Chengdu Jinshan Chemical Reagent Co., Ltd., China); CCK-8 solution (Japan Tongren Chemical Research Institute, China); annexin V-FITC/PI double-stained cell apoptosis detection kit (BD; San Diego, USA); intracellular ROS detection kit (Sigma, USA); JC-1 cell mitochondrial membrane potential detection kit and TUNEL apoptosis detection kit (Nanjing Kaiji Biotechnology Co., Ltd., China); DAPI and BCA protein assay kit (Beijing Suobao Biotechnology Co., Ltd., China); superoxide disproportionation enzyme detection kit and catalase detection kit (Nanjing, China); and malondialdehyde detection kit (Shanghai Biyuntian Biotechnology Co., Ltd., China).

\section{Isolation and culture of rabbit BMSCs}

In the present study, 4-6-week-old New Zealand white rabbits were used. Under sterile conditions, the bone marrow fluid was taken from the distal femur and proximal humerus, and the cells were separated by density gradient centrifugation. Then, these were incubated in a cell incubator $\left(37{ }^{\circ} \mathrm{C}, 5 \% \mathrm{CO}_{2}\right)$. When the primary cells reached $80-90 \%$ of confluence, these are passaged at a ratio of 1:3. Cells passaged up to the 3rd generation were used for the experimental treatment. 
Establishment of the oxidative stress model for BMSCs The 3rd generation BMSCs were divided into three groups: control group, high-concentration $\mathrm{H}_{2} \mathrm{O}_{2}$ injury group $(500 \mu \mathrm{M})$, and low-concentration $\mathrm{H}_{2} \mathrm{O}_{2}$ pretreatment group $(50 \mu \mathrm{M}+500 \mu \mathrm{M})$. When cell confluence reached approximately $80 \%$, according to the experimental group, the low-concentration $\mathrm{H}_{2} \mathrm{O}_{2}$ pretreatment group was first treated with $50 \mu \mathrm{M}$ of $\mathrm{H}_{2} \mathrm{O}_{2}$ for $8 \mathrm{~h}$, recovered for $12 \mathrm{~h}$, and finally treated with $500 \mu \mathrm{M}$ of $\mathrm{H}_{2} \mathrm{O}_{2}$ for $24 \mathrm{~h}$, the high-concentration $\mathrm{H}_{2} \mathrm{O}_{2}$ injury group was directly treated with $500 \mu \mathrm{M}$ of $\mathrm{H}_{2} \mathrm{O}_{2}$ for $24 \mathrm{~h}$, and the control group was routinely cultured.

\section{Detection of intracellular ROS}

The detection of cellular ROS was carried out using the fluorescent probe DCFH-DA, which can be oxidized to the progesterone high-fluorescent compound dichlorofluorescein (DCF). Then, these cells were incubated with DCFH-DA for $30 \mathrm{~min}$ at $37{ }^{\circ} \mathrm{C}$ and washed twice with phosphate-buffered saline (PBS). The fluorescence intensity was observed using a laser confocal microscope. Five fields were randomly selected under a high-power microscope, and the fluorescence intensity was calculated by fluorescence expression.

Evaluation of SOD, MDA, and CAT activity After cells are treated with $\mathrm{H}_{2} \mathrm{O}_{2}$, these cells were digested with trypsin and centrifuged at $1000 \mathrm{rpm}$ for $10 \mathrm{~min}$, and the cell pellet was collected. Then, these cells were disrupted by ultrasonography, centrifuge for $10 \mathrm{~min}$ at 12,000 rpm, and the supernatant was taken for the experiment. Each indicator was tested according to kit instructions.

\section{Detection of cell activity by CCK-8}

After cells are treated with $\mathrm{H}_{2} \mathrm{O}_{2}$, these cells were washed three times with PBS, and $100 \mu \mathrm{L}$ of a complete medium and $10 \mu \mathrm{L}$ of CCK- 8 solution were added to each well. After incubation for $2 \mathrm{~h}$, the enzyme-linked immunosorbent assay was performed at $450 \mathrm{~nm}$. Then, the absorbance value (OD) was measured.

\section{Annexin V-FITC/PI-detected apoptosis}

The $\mathrm{H}_{2} \mathrm{O}_{2}$-treated cells were washed twice with PBS, and these cells were resuspended in binding buffer. Then, 100 $\mu \mathrm{L}$ of the cell suspension was transferred to a 5 -ml centrifuge tube, and $5 \mu \mathrm{L}$ of FITC and $5 \mu \mathrm{L}$ of propidium iodide (PI) were added. Next, these cells were gently vortexed and incubated for $15 \mathrm{~min}$ in the dark at room temperature $\left(25^{\circ} \mathrm{C}\right)$. Afterwards, $400 \mu \mathrm{L}$ of binding buffer was added to each tube and analyzed by flow cytometry.

\section{TUNEL and DAPI double staining detection of cell apoptosis}

Cells were washed with PBS, fixed in $4 \%$ formaldehyde solution for $25 \mathrm{~min}$ at $4{ }^{\circ} \mathrm{C}$, and washed with PBS for 5 min, for three times. Then, $1 \%$ Triton X-100 was incubated for $5 \mathrm{~min}$ at room temperature and washed five times with PBS for three times. Afterwards, $50 \mu \mathrm{L}$ of equilibration buffer was added to each group and equilibrated for $10 \mathrm{~min}$ at room temperature. Subsequently, cells were incubated with $50 \mu \mathrm{L}$ of TdT working solution for $60 \mathrm{~min}$ in the dark at $37{ }^{\circ} \mathrm{C}$. Five fields were randomly selected for the high-power microscope for apoptotic cell counting, and each experiment group was repeated at least three times.

Observation of mitochondrial membrane potential by JC-1 JC-1 was prepared according to the manufacturer's instructions. Cells were incubated with the stains for 30 min at $37{ }^{\circ} \mathrm{C}$ and washed three times with PBS. Finally, the fluorescence was observed under a laser confocal microscope. Five fields were randomly selected under a high-power microscope, and the red/green fluorescence intensity ratio was calculated. Each experiment group was calculated for at least three times.

\section{Statistical methods}

All data were analyzed using SPSS 19.0 statistical software. Measurement data were expressed as mean \pm standard deviation $(\bar{x} \pm \mathrm{SD})$. One-way analysis of variance was used for multiple comparisons. The LSD $t$ test was used for comparisons between groups. $P<0.05$ was considered statistically significant.

\section{Results}

Changes in cell morphology after $\mathrm{H}_{2} \mathrm{O}_{2}$ induction

Cells not treated with $\mathrm{H}_{2} \mathrm{O}_{2}$ had normal cell morphology, were spindle-shaped, and had few apoptotic cells (Fig. 1a). Cells in the high-concentration $\mathrm{H}_{2} \mathrm{O}_{2}$ treatment group became smaller, had a long spindle shape, and the number of apoptotic cells significantly increased (Fig. 1b). However, the morphology of cells in the low-concentration $\mathrm{H}_{2} \mathrm{O}_{2}$ pretreatment group did not significantly change, and the apoptosis was significantly reduced (Fig. 1c).

\section{Intracellular ROS}

The changes in absorption value and fluorescence intensity of each group were detected by a fluorescence microscope. The control group was not treated with $\mathrm{H}_{2} \mathrm{O}_{2}$, there was merely a very small amount of ROS in cells, and the content of ROS is (4.53 \pm 0.49$)$ (Fig. 2a). Compared with the control group, treatment with 500 $\mu \mathrm{M}$ of $\mathrm{H}_{2} \mathrm{O}_{2}$ for $24 \mathrm{~h}$ significantly increased ROS levels, and the content of ROS was $(88.3 \pm 7.67)$, which showed strong green fluorescence (Fig. 2b). It is suggested that 

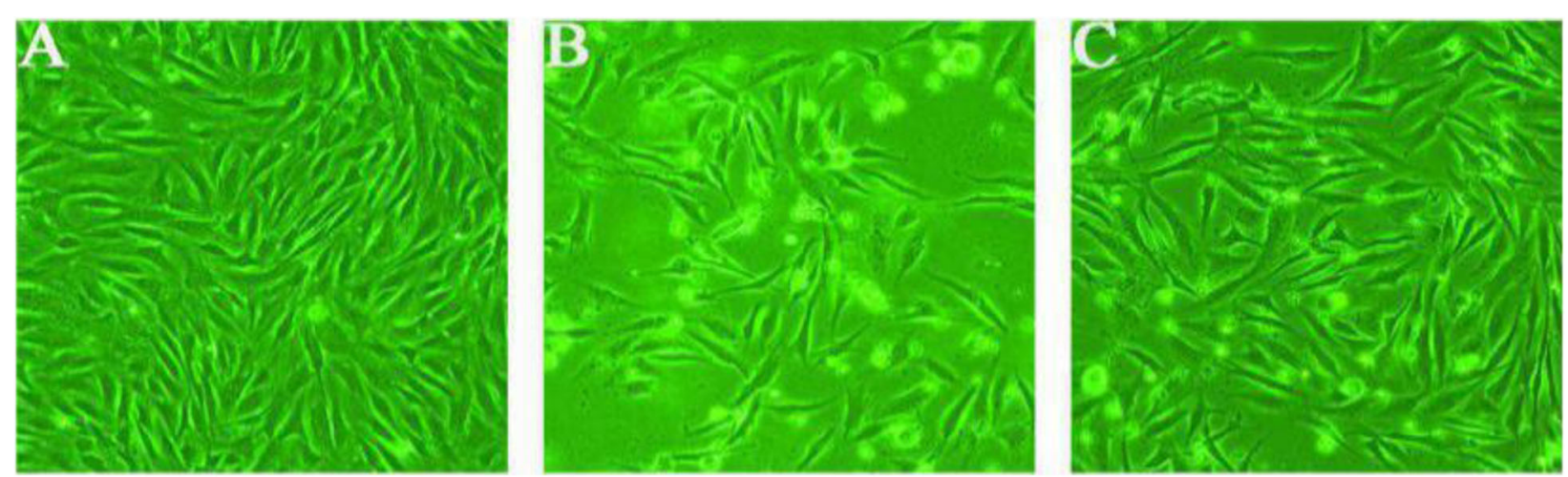

Fig. 1 Observation of cell morphology using an inverted phase-contrast microscope. a Control group $(\times 100)$; b High-concentration $\mathrm{H}_{2} \mathrm{O}_{2}$ injury group ( $\times 100)$; c Low-concentration $\mathrm{H}_{2} \mathrm{O}_{2}$ pretreatment group $(\times 100)$

excessive ROS is produced after being treated with a high concentration of $\mathrm{H}_{2} \mathrm{O}_{2}$. However, after pretreatment with $50 \mu \mathrm{M}$ of $\mathrm{H}_{2} \mathrm{O}_{2}$ for $8 \mathrm{~h}$, these intracellular ROS levels were effectively reduced, $(62.33 \pm 5.05)$ (Fig. $2 \mathrm{c})$, and the difference was statistically significant (Fig. 2d).

\section{SOD, MDA, CAT, and cell viability}

The experimental results show that MDA in the pretreatment group was $2.83 \pm 0.28 \mathrm{nmol} / \mathrm{mg}$ (Fig. 2e), while SOD, CAT, and cell viability were $34.11 \pm 1.72 \mathrm{U} /$ $\mathrm{mg}, 17.59 \pm 0.68 \mathrm{U} / \mathrm{mg}$, and $77.08 \pm 4.88 \%$, respectively (Figs. 2f-h). Compared with non-pretreatment, MDA content significantly decreased, SOD, CAT, and cell viability increased. These results suggest that $50-\mu \mathrm{M} \mathrm{H} \mathrm{H}_{2} \mathrm{O}_{2}$ pretreatment can improve the oxidative damage of cells by increasing the activities of endogenous antioxidant enzymes.

\section{Intracellular mitochondrial membrane potential}

The protective effect of low-concentration $\mathrm{H}_{2} \mathrm{O}_{2}$ pretreatment on mitochondria could be observed by JC-1 staining. Normal cells revealed high red and high green fluorescence (Fig. 3a). However, when cells were exposed to high concentrations of $\mathrm{H}_{2} \mathrm{O}_{2}(500 \mu \mathrm{M})$ for $24 \mathrm{~h}, \Delta \psi \mathrm{m}$ rapidly depolarized, the green fluorescence increased, and the red fluorescence decreased, the ratio of red to green is $36.34 \pm 5.62 \%$ (Fig. 3b). After the $50-\mu \mathrm{M} \mathrm{H} \mathrm{H}_{2} \mathrm{O}_{2}$ pretreatment, the green fluorescence intensity was reduced and red fluorescence was restored, and the ratio of red to green is $66.52 \pm 4.71 \%$ (Fig. 3c). The
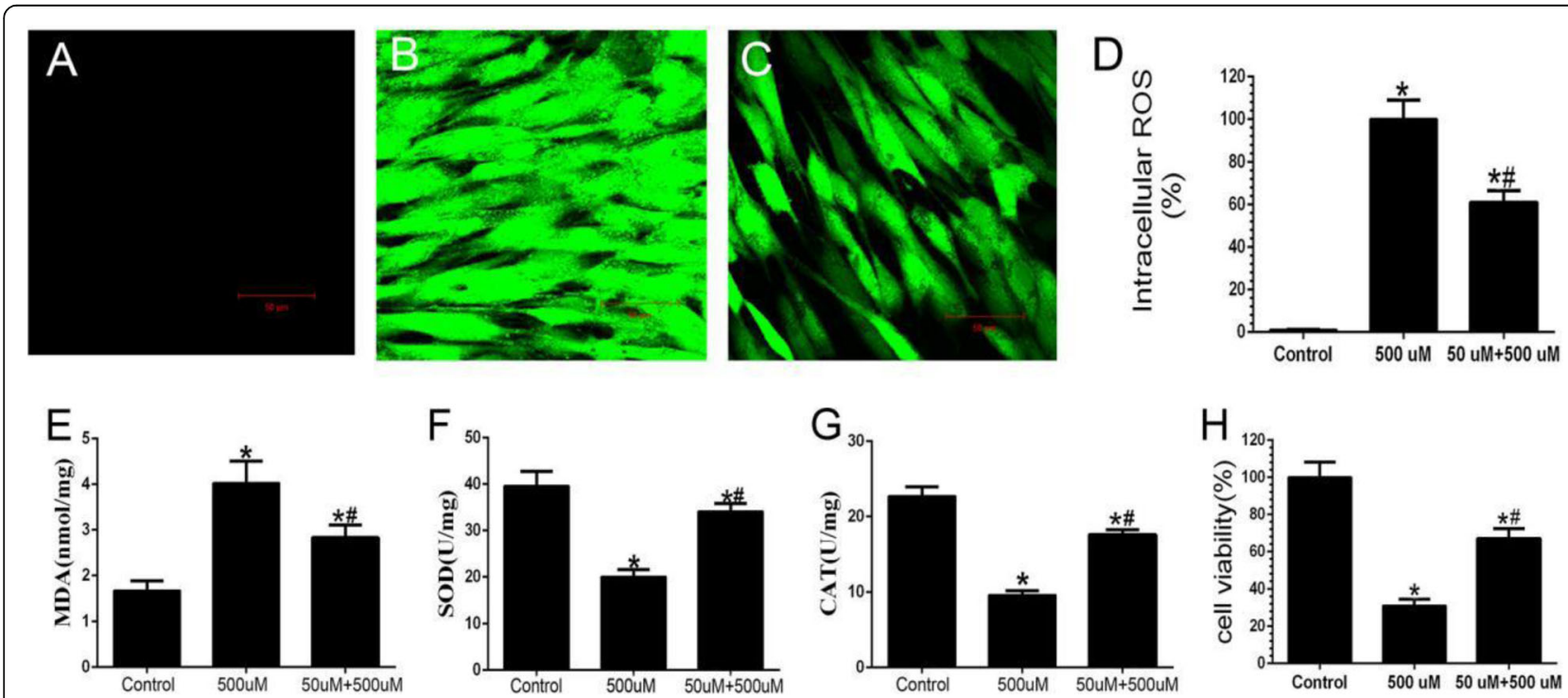

Fig. 2 Detection of intracellular ROS, MDA, SOD, CAT, and cell viability. a-c Detection of ROS, control group, high-concentration $\mathrm{H}_{2} \mathrm{O}_{2}$ injury group and Low-concentration $\mathrm{H}_{2} \mathrm{O}_{2}$ pretreatment group respectively $(\times 100)$; d Quantitative analysis of DCF fluorescence intensity; e Intracellular MDA content; $\mathbf{f}$ Intracellular SOD viability; $\mathbf{g}$ Intracellular CAT viability; $\mathbf{h}$ Cell viability; $n=5$; Compared with the control group, ${ }^{*} P<0.05$; Compared with the high-concentration $\mathrm{H}_{2} \mathrm{O}_{2}$ injury group, ${ }^{\#} P<0.05$ 

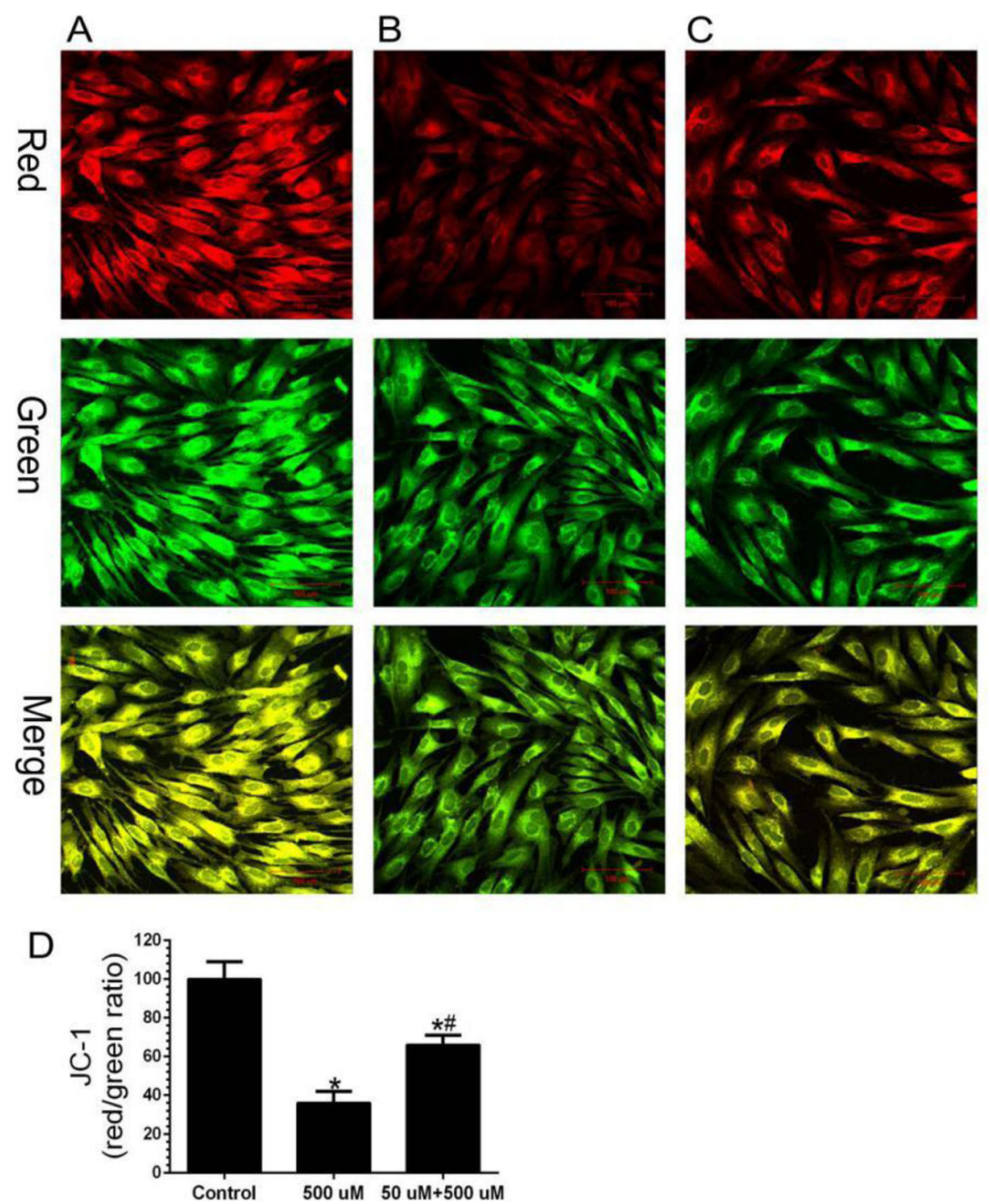

Fig. 3 Detection of mitochondrial membrane potential by JC-1. a Control group ( $\times 400$ ); b High-concentration $\mathrm{H}_{2} \mathrm{O}_{2}$ injury group ( $\times 400$ ). c Lowconcentration $\mathrm{H}_{2} \mathrm{O}_{2}$ pretreatment group $(\times 400)$. d Quantitative analysis of membrane potential changes; $n=3$; Compared with the control group, " $P<0.05$; Compared with the high-concentration $\mathrm{H}_{2} \mathrm{O}_{2}$ injury group, ${ }^{\#} P<0.05$

pretreatment group was 1.8 times higher than the nonpretreatment group (Fig. 3d). This suggests that lowconcentration $\mathrm{H}_{2} \mathrm{O}_{2}$ pretreatment can achieve antiapoptotic effects by inhibiting the mitochondrial damage pathway.

\section{Annexin-V/PI double staining was used to detect apoptosis}

The annexin V/PI apoptosis assay revealed that the apoptotic rate was $2.56 \pm 0.17 \%$ in the blank group (Fig. 4a) and $39.67 \pm 3.20 \%$ in the non-pretreatment group (Fig. $4 \mathrm{~b})$. Compared with non-pretreatment, the apoptosis rate in the pretreatment group significantly decreased, $24.26 \pm$ $2.10 \%$ (Fig. 4c), and the difference was statistically significant (Fig. 4d). Hence, a low-concentration $\mathrm{H}_{2} \mathrm{O}_{2}$ pretreatment reduces apoptosis and promotes cell survival under oxidative stress.

\section{TUNEL/DAPI detects apoptosis}

The results of apoptosis detected by TUNEL/DAPI method showed that compared with the control group (Fig. 5a), the proportion of TUNEL-positive cells in the high-concentration $\mathrm{H}_{2} \mathrm{O}_{2}$ injury group significantly increased, and the apoptosis was $25.72 \pm 2.33 \%$ (Fig. 5b). However, the proportion of TUNEL-positive cells decreased in the low-concentration $\mathrm{H}_{2} \mathrm{O}_{2}$ pretreatment group, and the apoptosis rate was $12.67 \pm 0.72 \%$ (Fig. 5c). Compared with the non-pretreatment group, the apoptosis 

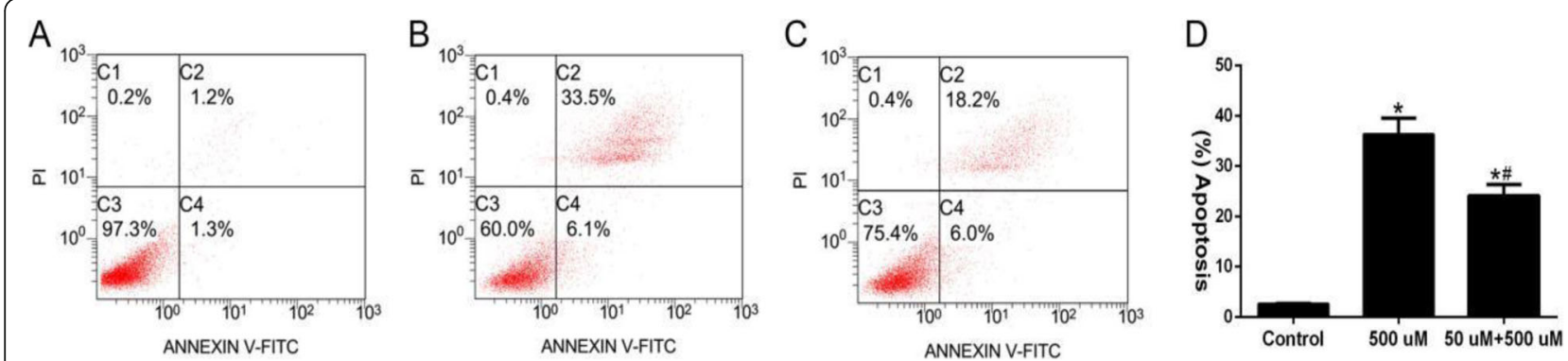

Fig. 4 Apoptosis detected by annexin-V/PI staining. a Control group ( $\times 400)$; b High-concentration $\mathrm{H}_{2} \mathrm{O}_{2}$ injury group ( $\left.\times 400\right)$; c Low-concentration $\mathrm{H}_{2} \mathrm{O}_{2}$ pretreatment group ( $\left.\times 400\right)$; d Quantitative analysis of cell apoptosis; $n=3$; Compared with the control group, ${ }^{*} P<0.05$; Compared with the high-concentration $\mathrm{H}_{2} \mathrm{O}_{2}$ injury group, ${ }^{\#} P<0.05$

rate of the pretreatment group decreased by approximately $1 / 2$ (Fig. 5b). These results suggest that pretreatment can significantly reduce BMSC apoptosis under oxidative stress.

\section{Discussions}

The ischemic and hypoxic microenvironment in osteonecrosis area makes cells suffer strong oxidative stress, resulting in changes and loss of cell function, inhibition of cell proliferation, and apoptosis, which seriously affects the effect of cell therapy [11, 12]. Studies have shown that the oxidative stress microenvironment in the ischemic necrotic area of the femoral head causes the grafted BMSCs to suffer oxidative stress, causes a large amount of ROS, in BMSCs to induce premature senescence and apoptosis of BMSCs, and decreases the proliferation and osteogenic differentiation of surviving BMSCs, which seriously affects the repair effect of the tissue-engineered bone on ANFH [13]. Strengthening the anti-oxidant stress ability of BMSCs in the transplantation area is the key to improve the curative effect of transplantation.

Numerous studies have shown that pre-repeated short-term low-intensity damage stimulation can induce cells or the body to tolerate the subsequently sustained similar high-intensity damage stimulation, which is a ubiquitous adaptive protection phenomenon. Liu and other studies [14] have shown that after myocardial infarction in rats, the transplantation of cardiac progenitor cells (CPCs) and the $\mathrm{H}_{2} \mathrm{O}_{2}$ pretreatment of CPCs can significantly improve the survival rate of CPCs, improve ventricular systolic function, and improve efficacy. $\mathrm{Li}$ and other reports [15] on diabetic cardiomyopathy, high glucose, and the $\mathrm{H}_{2} \mathrm{O}_{2}$ pretreatment of mesenchymal stem cells (MSCs) can significantly improve the survival, proliferation, and angiogenesis of MSCs and promote cardiac repair. Therefore, in this study, we used the oxidative stress model of BMSCs induced by $\mathrm{H}_{2} \mathrm{O}_{2}$. BMSCs were pretreated with a low concentration of $\mathrm{H}_{2} \mathrm{O}_{2}$ at first, and then, the effect was observed under the condition of a high concentration of $\mathrm{H}_{2} \mathrm{O}_{2}$. It was found that pretreatment with a low concentration of $\mathrm{H}_{2} \mathrm{O}_{2}$ could significantly improve the resistance of BMSCs to oxidative stress.

As our experimental results show, after treating BMSCs with high concentrations of $\mathrm{H}_{2} \mathrm{O}_{2}$, the flow cytometry revealed that the apoptotic rate significantly increased after treatment with high concentrations of $\mathrm{H}_{2} \mathrm{O}_{2}$, and the apoptotic rate was $39.67 \pm 3.20 \%$, and cell viability was $31.13 \pm 2.11 \%$. Furthermore, DAPI staining revealed that some of the nucleus contractions became smaller, and the nucleoplasm was densely stained or fragmented. This indicates that these cells were obviously damaged, suggesting that the oxidative stress environment was not conducive to the survival of BMSCs. However, when cells were pretreated with $50-\mu \mathrm{M}$ lowconcentration $\mathrm{H}_{2} \mathrm{O}_{2}$ for $8 \mathrm{~h}$, cell viability significantly increased to $67.09 \pm 5.38 \%$, and the apoptosis rate was $24.26 \pm 2.10 \%$ in the pretreatment group. These results show that apoptosis was significantly lower than that in the high-concentration injury group, and the cell viability rate increased significantly. This confirms that low-concentration $\mathrm{H}_{2} \mathrm{O}_{2}$ pretreatment could significantly improve the cell survival of BMSCs after oxidative stress injury and inhibit the apoptosis.

The occurrence of apoptosis is a complex process that involves multiple factors, ROS production, mitochondrial depolarization, chromatin agglutination, and nuclear fission [16]. ROS is a general term for oxygen-containing free radicals and free radical-forming peroxides associated with oxygen metabolism in living organisms, and the oxidizing properties are very active [17]. ROS can cause membrane lipid peroxidation, protein cross-linking and degradation, deoxyribonucleic acid cleavage, and the mitochondrial dysfunction of BMSCs [18]. Under physiological conditions, the body continuously produces active oxygen, and the body's antioxidant system continuously removes active oxygen, which is in a dynamic equilibrium, and does not damage the body [19]. However, when harmful stimuli occur, a large amount of active oxygen is generated, and 

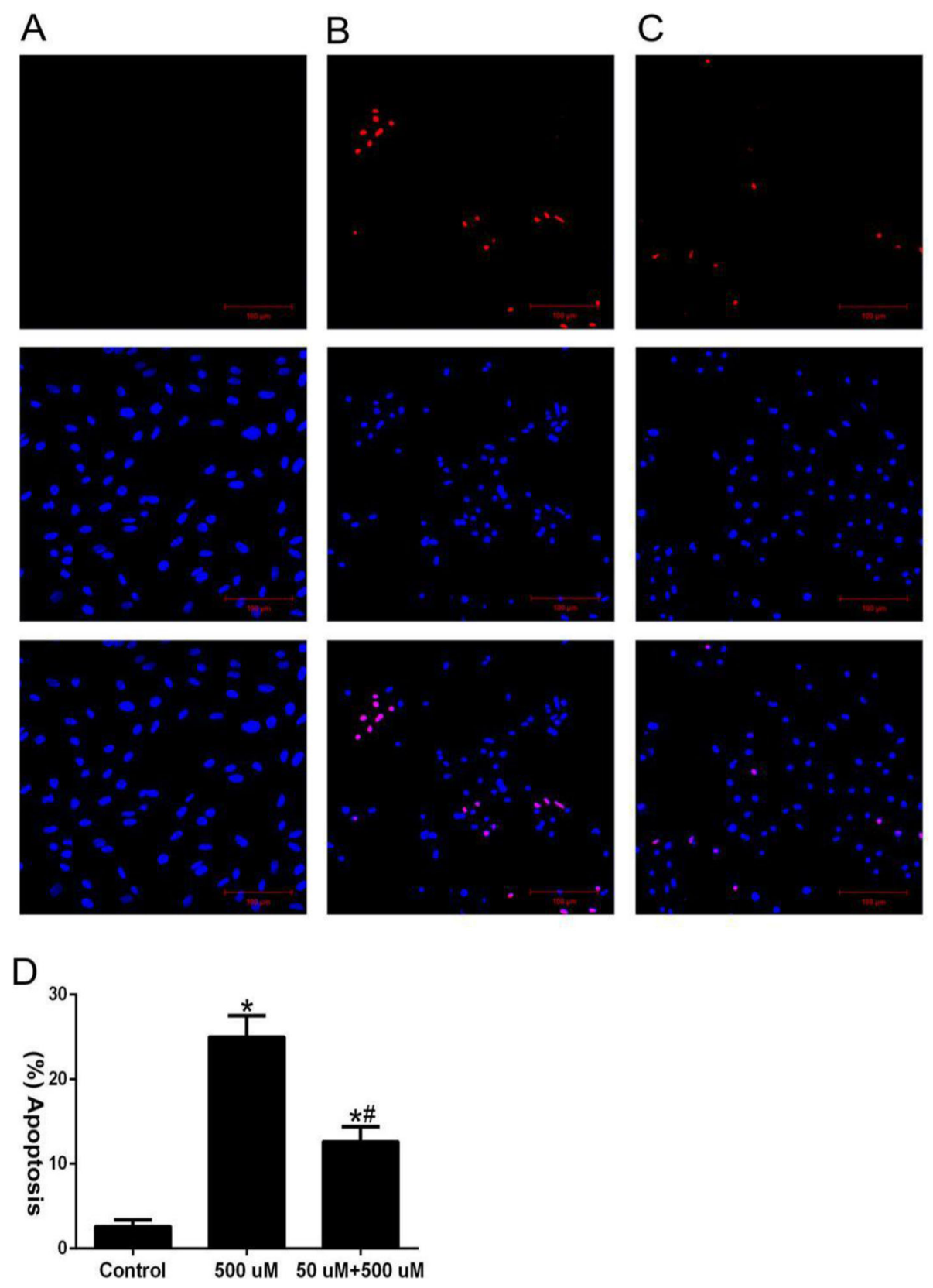

Fig. 5 Apoptosis detected by TUNEL/DAPI staining. a Control group ( $\times 400)$; b High-concentration $\mathrm{H}_{2} \mathrm{O}_{2}$ injury group ( $\left.\times 400\right)$; c Low-concentration $\mathrm{H}_{2} \mathrm{O}_{2}$ pretreatment group $(\times 400)$; d Quantitative analysis of cell apoptosis; $n=3$; Compared with the control group, ${ }^{*} P<0.05$; Compared with the high-concentration $\mathrm{H}_{2} \mathrm{O}_{2}$ injury group, ${ }^{\#} P<0.05$

the antioxidant system has limited the ability to remove these, eventually leading to oxidative damage [20]. The main systems for scavenging ROS in cells are antioxidant enzymes such as SOD and CAT, the intracellular levels of both of them can represent the changes of intracellular anti-oxidant capacity to a certain extent. The present experiment revealed that pretreatment with a low concentration of $\mathrm{H}_{2} \mathrm{O}_{2}$ can significantly reduce the production of intracellular ROS and reduce cellular oxidative stress damage. The results show that the activities of SOD and CAT in a low-concentration $\mathrm{H}_{2} \mathrm{O}_{2}$ pretreatment group were significantly higher than those in a high-concentration $\mathrm{H}_{2} \mathrm{O}_{2}$ injury group, and the contents of MDA and ROS decreased significantly, suggesting that $\mathrm{H}_{2} \mathrm{O}_{2}$ pretreatment may increase the activity of SOD and CAT, so as to enhance the resistance to oxidative damage.

Mitochondria are the energy and metabolic centers of eukaryotes and are also organelles that play a key regulatory role in apoptosis and signaling [21]. The mitochondrial membrane potential declined as a preliminary 
event of apoptosis. Oxidative stress injury leads to apoptosis through the mitochondrial pathway, which destroys the stability of the mitochondrial membrane, causes cytochrome $\mathrm{C}$ to be released from the mitochondria to the cytoplasm, then binds to the apoptotic protein activator in the cytoplasm, and leads to apoptosis by proteolysis [22]. In this study, the mitochondrial membrane potential of cells was detected using JC-1 method, and damage to the mitochondrial membrane potential induced by $\mathrm{H}_{2} \mathrm{O}_{2}$ was observed [23]. When the mitochondrial membrane potential becomes high, JC-1 forms a polymer that produces red fluorescence, while when the mitochondrial membrane potential is low, it produces a green fluorescence. This allows changes in the mitochondrial membrane potential to be detected by fluorescence color transitions $[24,25]$. In our results, the red fluorescence in the high-concentration $\mathrm{H}_{2} \mathrm{O}_{2}$ injury group could be observed, the green fluorescence was significantly lower, and the ratio of red to green is 36.34 $\pm 5.62 \%$, indicating that $\mathrm{H}_{2} \mathrm{O}_{2}$ can decrease the mitochondrial membrane potential. Furthermore, the red-green ratio in the pretreatment group significantly increased, the ratio is $66.52 \pm 4.71 \%$, indicating that these cells maintained a high membrane potential level. These results show that low-concentration $\mathrm{H}_{2} \mathrm{O}_{2}$ pretreatment can maintain the mitochondrial membrane potential level and protect mitochondrial function to some extent.

The limitations of the present study include the following, although this experimental study proved that oxidative stress preconditioning significantly enhanced the antioxidant stress of cells, but there are still many problems that have not been clarified. The mechanism of preconditioning enhancing antioxidant stress is not completely clear, which signals are regulated by preconditioning. In addition, our study only explored the enhancement of antioxidant stress by oxidative stress preconditioning in vitro. When BMSCs are used for transplantation in vivo, there are many factors affecting its survival, such as post-injury ischemia, hypoxia microenvironment, and various inflammatory factors. Therefore, on how to improve the efficiency of BMSC transplantation, there are still many problems to be studied.

In conclusion, low-concentration $\mathrm{H}_{2} \mathrm{O}_{2}$ pretreatment can significantly increase the activity of SOD and CAT after oxidative stress injury, reduce the levels of ROS and MDA in cells, alleviate DNA and mitochondrial membrane damage, reduce cell apoptosis, and significantly promote the survival of BMSCs under oxidative stress conditions.

\section{Abbreviations}

BMSCs: Bone marrow mesenchymal stem cells; $\mathrm{H}_{2} \mathrm{O}_{2}$ : Hydrogen peroxide; ROS: Reactive oxygen species; SOD: Superoxide dismutase; CAT: Catalase;
MDA: Malondialdehyde; SPF: Specific pathogen-free; PBS: Phosphate-buffered saline; OD: Absorbance value; CPCs: Cardiac progenitor cells

\section{Acknowledgements}

Not applicable.

\section{Authors' contributions}

W.X.P. and L.W. designed the research and drafted the manuscript. D.J.Y. performed and analyzed most of the experiments. F.Z., J.Z., and W.T.D. analyzed the data. Z.W.W. assisted with the cell isolation and culture. Y.G.Z. assisted with the establishment of the oxidative stress cell model. T.W. assisted with the detection of ROS, mitochondrial membrane potential, apoptosis, and other indicators. The author(s) read and approved the final manuscript.

\section{Funding}

This work was supported by a grant from the Guizhou Provincial Health and Family Planning Commission Fund Project (No. gzwjkj2016-1-001,

gzwjkj2018-1-008), the Guizhou Provincial Science and Technology Fund Project (No. [2017]7197), and the Guiyang Science and Technology Fund Project (No. [2017]5-2).

\section{Availability of data and materials}

The datasets during and/or analyzed during the current study available from the corresponding author on reasonable request.

\section{Ethics approval and consent to participate}

This study was done according to the NIH Guide for the Care and Use of Laboratory Animals (NIH Publication, 8th Edition. Revised 2011). Approval was received from the Animal Care Welfare Committee of Guizhou Medical University (ID: 1800815).

\section{Consent for publication}

Not applicable.

\section{Competing interests}

The authors declare that they have no competing interests.

\section{Author details}

${ }^{1}$ Department of Orthopedics, The Affliated Hospital of Guizhou Medical University, Guiyang 550004, Guizhou, China. 'uizhou Medical University, Guiyang 550004, Guizhou, China.

Received: 14 May 2020 Accepted: 24 August 2020

Published online: 09 September 2020

\section{References}

1. Hu W, Jing $P$, Wang $L$, Zhang $Y$, Yong J, Wang $Y$. The positive effects of Ginsenoside Rg1 upon the hematopoietic microenvironment in a DGalactose-induced aged rat model. BMC Complement Altern Med. 2015;15: 107-19. PMID: 25881060

2. Thanan R, Techasen A, Hou B, Jamnongkan W, Armartmuntree N, Yongvanit $P$, Murata M. Development and characterization of a hydrogen peroxideresistant cholangiocyte cell line: a novel model of oxidative stress-related cholangiocarcinoma genesis. Biochem Biophys Res Commun. 2015;464:1828. PMID: 26100205.

3. Serbest $\mathrm{S}$, Tiftikçi U, Tosun HB, Kısa Ü. The irisin hormone profile and expression in human bone tissue in the bone healing process in patients. Med Sci Monit. 2017;23:4278-83. PMID: 28869754.

4. Serbest S, Tiftikci U, Tosun HB, Gumustas SA, Uludag A. Is there a relationship between fracture healing and mean platelet volume? Ther Clin Risk Manag. 2016;12:1095-9. PMID: 27471388.

5. Salazar-Noratto GE, Luo G, Denoeud C, et al. Understanding and leveraging cell metabolism to enhance mesenchymal stem cell transplantation survival in tissue engineering and regenerative medicine applications. Stem Cells. 2020;38(1):22-33. PMID: 31408238.

6. Denu RA, Hematti P. Effects of oxidative stress on mesenchymal stem cell biology. Oxidative Med Cell Longev. 2016;2016:2989076. PMID: 27413419.

7. Deng G, Niu K, Zhou F, Li B, Kang Y, Liu X, Hu J, Li B, Wang Q, Yi C, Wang Q. Treatment of steroid-induced osteonecrosis of the femoral head using 
porous $\mathrm{Se}_{\mathrm{SiO}}$ nanocomposites to suppress reactive oxygen species. Sci Rep. 2017;7:43914. PMID: 28256626.

8. Xu C, Luo J, He L, Montell C, Perrimon N. Oxidative stress induces stem cell proliferation via TRPA1/RyR-mediated $\mathrm{Ca}^{2+}$ signaling in the Drosophila midgut. Elife. 2017;6:e22441. PMID: 28561738.

9. Ren M, Yang S, Li J, et al. Ginkgo biloba L. extract enhances the effectiveness of syngeneic bone marrow mesenchymal stem cells in lowering blood glucose levels and reversing oxidative stress. Endocrine. 2013:43(2):360-9. PMID: 22815043

10. Shadab M, Jha B, Asad M, et al. Apoptosis-like cell death in Leishmania donovani treated with KalsomeTM10, a new liposomal amphotericin B. PLoS One. 2017;12(2):1-31. PMID: 28170432.

11. Bing W, Pang X, Qu Q, et al. Simvastatin improves the homing of BMSCs via the PI3K/AKT/miR-9 pathway. J Cell Mol Med. 2016;20(5):949-61. PMID: 26871266.

12. Shi-Cong $T$, Ting $Y$, Bi-Yu R, et al. Exosomes derived from human plateletrich plasma prevent apoptosis induced by glucocorticoid-associated endoplasmic reticulum stress in rat osteonecrosis of the femoral head via the Akt/Bad/Bcl-2 signal pathway. Theranostics. 2017;7(3):733-50. PMID: 28255363.

13. Fan L, Zhang C, Yu Z, Shi Z, Dang X, Wang K. Transplantation of hypoxia preconditioned bone marrow mesenchymal stem cells enhances angiogenesis and osteogenesis in rabbit femoral head osteonecrosis. Bone. 2015;81:544-53. PMID: 26363339.

14. Liu D, Zhang H, Gu W, Liu Y, Zhang M. Neuroprotective effects of ginsenoside $\mathrm{Rb} 1$ on high glucose-induced neurotoxicity in primary cultured rat hippocampal neurons. PLoS One. 2013;8:793-9. PMID: 24223941.

15. Li Y, Zhang Y, Wang T, Podok P, Xu D, Lu L. Proteomic identification and characterization of Ctenopharyngodon idella tumor necrosis factor receptorassociated protein 1 (CiTrap1): an anti-apoptosis factor upregulated by grass carp reovirus infection. Fish Shellfish Immunol. 2015;43:449-59. PMID: 25655331.

16. Zhang R, Zhang N, Zhang H, Liu C, Dong X, Wang X, Zhu Y, Xu C, Liu L, Yang $S$, Huang $S$, Chen L. Celastrol prevents cadmium-induced neuronal cell death by blocking reactive oxygen species-mediated mammalian target of rapamycin pathway. Br J Pharmacol. 2017;174:82-100. PMID: 27764525.

17. Zhou Y, He W, Sun W, Zhou Z, Sun M, Xia P, Li W, Zheng M, Zhang L, Ni J, Gao K. Sulfotanshinone IIA sodium ameliorates glucose peritoneal dialysis solution-induced human peritoneal mesothelial cell injury via suppression of ASK1-P38-mediated oxidative stress. Cell Physiol Biochem Int J Exp Cell Physiol Biochem Pharmacol. 2018;46:24-34. PMID: 29742502.

18. He R, Cui M, Lin H, Zhao L, Wang J, Chen S, Shao Z. Melatonin resists oxidative stress-induced apoptosis in nucleus pulposus cells. Life Sci. 2018; 199:122-30. PMID: 29526797.

19. Zhou Y, Huang S, Shen H, Ma M, Zhu B, Zhang D. Detection of glutathione in oral squamous cell carcinoma cells with a fluorescent probe during the course of oxidative stress and apoptosis. J Oral Maxillofac Surg. 2016;75: 223-33. PMID: 27637779

20. Bebensee DF, Can K, Müller M. Increased mitochondrial mass and cytosolic redox imbalance in hippocampal astrocytes of a mouse model of rett syndrome: subcellular changes revealed by ratiometric imaging of JC-1 and roGFP1 fluorescence. Oxidative Med Cell Longev. 2017:17:306-21. PMID: 28894505.

21. Wang LL, Yu QL, Han L, Ma XL, Song RD, Zhao SN, Zhang WH. Study on the effect of reactive oxygen species-mediated oxidative stress on the activation of mitochondrial apoptosis and the tenderness of yak meat. Food Chem. 2018;24:386-94. PMID: 29120799.

22. Li W, Liu Y, Wang B, et al. Protective effect of berberine against oxidative stress-induced apoptosis in rat bone marrow-derived mesenchymal stem cells. Exp Therapeutic Med. 2016;12(6):4041-8. PMID: 28101183.

23. Xue T, Luo P, Zhu H, Zhao Y, Wu H, Gai R, Wu Y, Yang B, Yang X, He Q. Oxidative stress is involved in Dasatinib-induced apoptosis in rat primary hepatocytes. Toxicol Appl Pharmacol. 2012;261:267-80. PMID: 22538170.

24. Zorova LD, Popkov VA, Plotnikov EY, et al. Mitochondrial membrane potential. Anal Biochem. 2018;552:50-9. PMID: 28711444.

25. Chan S, Chan GC, Ye J, Lian Q, Chen J, Yang M. Thrombopoietin protects cardiomyocytes from iron-overload induced oxidative stress and mitochondrial injury. Cell Physiol Biochem. 2015;36:2063-71. PMID: 26202365.

\section{Publisher's Note}

Springer Nature remains neutral with regard to jurisdictional claims in published maps and institutional affiliations.

Ready to submit your research? Choose BMC and benefit from:

- fast, convenient online submission

- thorough peer review by experienced researchers in your field

- rapid publication on acceptance

- support for research data, including large and complex data types

- gold Open Access which fosters wider collaboration and increased citations

- maximum visibility for your research: over $100 \mathrm{M}$ website views per year

At BMC, research is always in progress.

Learn more biomedcentral.com/submissions 